\title{
PRESSURE REDISTRIBUTION IN WHEELCHAIR CUSHION FOR PARAPLEGICS: ITS APPLICATION AND EVALUATION
}

\author{
By A. G. Key, M.B., ChB. ${ }^{1}$, M. T. Manley, B.Sc., Ph.D., C.Eng., M.I.Mech.E. ${ }^{2}$ and \\ E. WAKEFIELD, Dip.Physio. ${ }^{1}$ \\ ${ }^{1}$ Conradie Hospital, Pinelands, Cape Town; and ${ }^{2}$ Department of Bio-engineering, Medical \\ School, University of Cape Town, Observatory, Cape Town, South Africa
}

Abstract. A survey of the first 200 cases supplied with a 'Paracare' pressure redistribution wheelchair cushion. The rationale of the design and material used is discussed. The method of application and follow-up studies are given and a total evaluation of the results achieved to date are presented.

Key words: Cushion; Pressure redistribution.

\section{Introduction}

IN the early I970s at the Spinal Unit at the Conradie Hospital, Cape Town there was a growing concern about the quality of the material being used in the manufacture of commercially available wheelchair cushions, as there was a noticeable increase in the incidence of sitting pressure sores. Previously cushions had been made of sponge rubber and were quite acceptable, this was however replaced with a plastic foam of far greater compliance. In July 1976, work which had been done at the University of Strathclyde, Scotland, was introduced to the Spinal Unit in Cape Town, which initiated the establishment of a weekly 'pressure clinic' and research into the design of and the selection of a more suitable locally available material for the manufacture of an acceptable body support for wheelchair users.

The soft tissues covering the ischial tuberosities, with their relatively small surface area are very liable to suffer from pressure ischaemia. Measurements of interface pressures occurring under the ischii are revealing. Pressures of up to $300 \mathrm{~mm} \mathrm{Hg}$ have been measured under a subject sitting on a wooden chair, and in excess of $100 \mathrm{~mm} \mathrm{Hg}$ under a subject on a soft plastic foam cushion on a wheelchair seat (Manley, Wakefield and Key, 1977). As the mean capillary blood pressure is only about $30-40 \mathrm{~mm} \mathrm{Hg}$ (Burton and Yamada I95I), this degree of tissue loading, if prolonged, will lead to tissue necrosis and pressure sore formation. In addition any tendency to cushion sag will give rise to frictional and sheer forces which will further deform the loaded tissues and cause further capillary occlusion.

Cushions designed for long-term sitting, when sacral anaesthesia is present, can be divided into either passive or active categories. The passive category, attempts to statically distribute the weight as evenly as possible whilst the active provides a constantly alternating patient/support contact area.

Passive: (I) Flotation pads-air water or silicone filled; (2) Bean bags-cloth envelopes filled usually with polystyrene beads; (3) Elastic and Visco-elastic foam cushions; and (4) Custom made vacuum formed seats providing maximum patient support contact area. 
Active: Ripple seat or alternating pressure pad.

Problems with support devices in the passive category include: instability, undue compressibility of the elastic foam, excessive weight in the case of fluid and gel pads, heat retention with bean bags and expense and mainteneance of the vacuum formed seats. In the active category ripple-type seats are cumbersome and require compressors and power supplies.

A cushion, shown in Fig. I, has been designed at the Conradie Hospital Spinal Unit which is relatively inexpensive, light weight and which, in the majority of cases, successfully redistributes the patients weight to acceptable tissue loading levels.

The cushion is constructed from expanded polyurethane elastic foam of high density which prevents cushion sag and 'bottoming out' of the pelvis into the wheelchair seat. A cut-out under the ischii of a specific size, individual to each patient, ensures that most of the load which would have been carried by the ischial areas is now carried on the trochanteric shelf and thighs. The ischii can safely withstand up to $30 \mathrm{~mm} \mathrm{Hg}$ so a block of low-density foam is placed in the base of the cutout in order that a small proportion of the body weight is still carried by the ischial areas, but the main load is taken by the trochanteric shelf and the thighs which by virtue of their much larger surface area can withstand higher interface pressures. The front portion of the cushion is raised ensuring that the maximum possible load is transferred to the 'safe' weight-bearing areas of the thighs whilst a curved base fills the sag of the wheelchair seat and thus prevents distortion of the cut-out dimensions and keeps the support surface flat. The

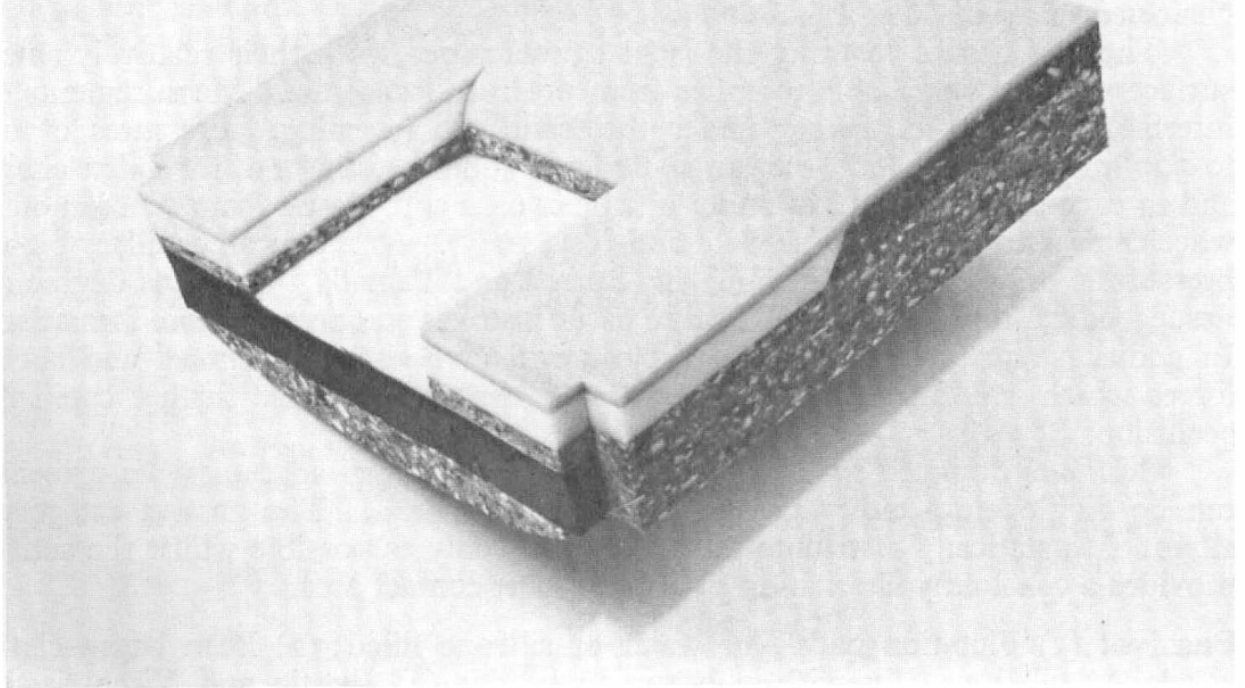

FIG. I

The 'Paracare' cushion uncovered. 
footplates of the chair should be so positioned to ensure an even distribution of pressure on the thighs.

The cushion is fitted with a two-way stretch fabric cover which prevents abrasive wear of the foam and a hammocking effect in the area of the cut-out.

In addition to the Paracare cushions most cases are also fitted with a shaped backrest (Fig. 2) of the same material, designed to ensure a 'no-load' condition over the sacrum, coccyx and vertebral spinous processes and centralisation of the ischii in the cutout of the cushion. It also improves the sitting posture and provides some degree of lateral stability for the high level spinal lesions. Location to the wheelchair (Figs. 3 and 4 ) is established with elastic loops over the wheelchair pushing handles and by velcro tapes to the backrest of the chair and the Paracare backrest.

FIG. 2

'Paracare' cushion and backrest. 


\section{The Conradie Pressure Clinic}

Our clinics are held weekly, and pressure measurements are taken under all sitting weight-bearing areas on whatever cushion the patient has previously been using. If these are considered satisfactory the patient may continue to use the same cushion. If not the patient is assessed, the level of the lesion is noted and recorded and the presence of pressure sores or undue tissue marking or discoloration is noted. The lateral separation of the ischial tuberosities is measured (Fig. 5) and the patient is fitted with the correct size of Paracare cushion (Fig. 6).

Once fitted with the correct cushion the wheelchair footrests are adjusted to maximise loading of the thighs and interface pressure measurements are taken

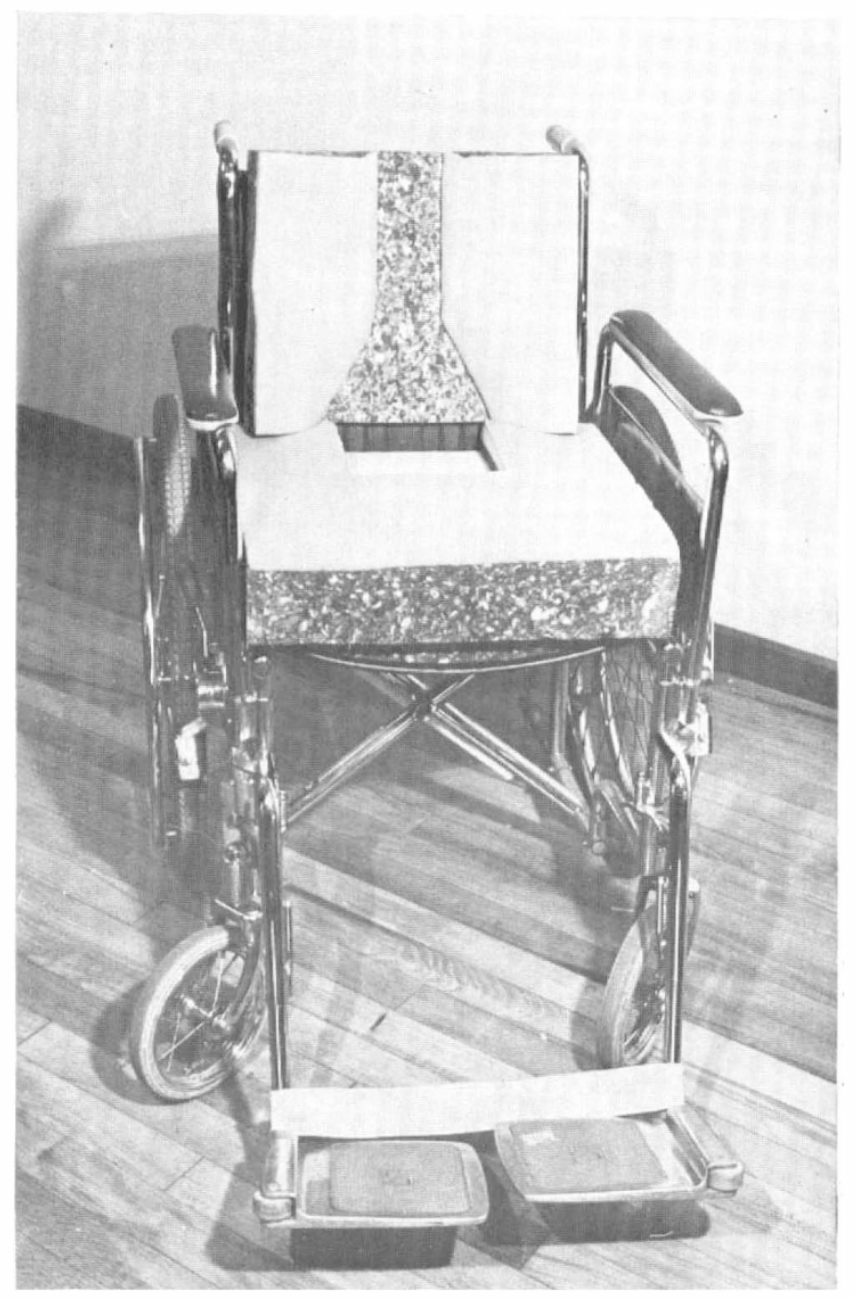

FIG. 3

Cushion and backrest in chair uncovered. 
across the sitting area at predetermined sites: (I) under each ischial tuberositymaximum $20 \mathrm{~mm} \mathrm{Hg}$; (2) under each trochanteric shelf-maximum $50 \mathrm{~mm} \mathrm{Hg}$; (3) under each pre-ischial area-maximum $60 \mathrm{~mm} \mathrm{Hg}$; and (4) under the anterior half of the thighs-maximum $80 \mathrm{~mm} \mathrm{Hg}$. If the measured pressures at any of the sites is greater, modifications are made to the cut-out size or by the addition of foam wedges or bars or by adjusting the height of the footrests.

Each patient fitted with a cushion is seen weekly for the first 3 weeks on the cushion, monthly thereafter for 3 months and then 6 monthly to ensure that interface pressures remain acceptable and that the patient is free from sores. Pressures are checked at each visit and adjustments are made where and when necessary (see Figs. 7 and 8)

Cushion design data for each patient is filled with the patient's notes so that a new cushion can be made at any time without repeating the measuring procedures.

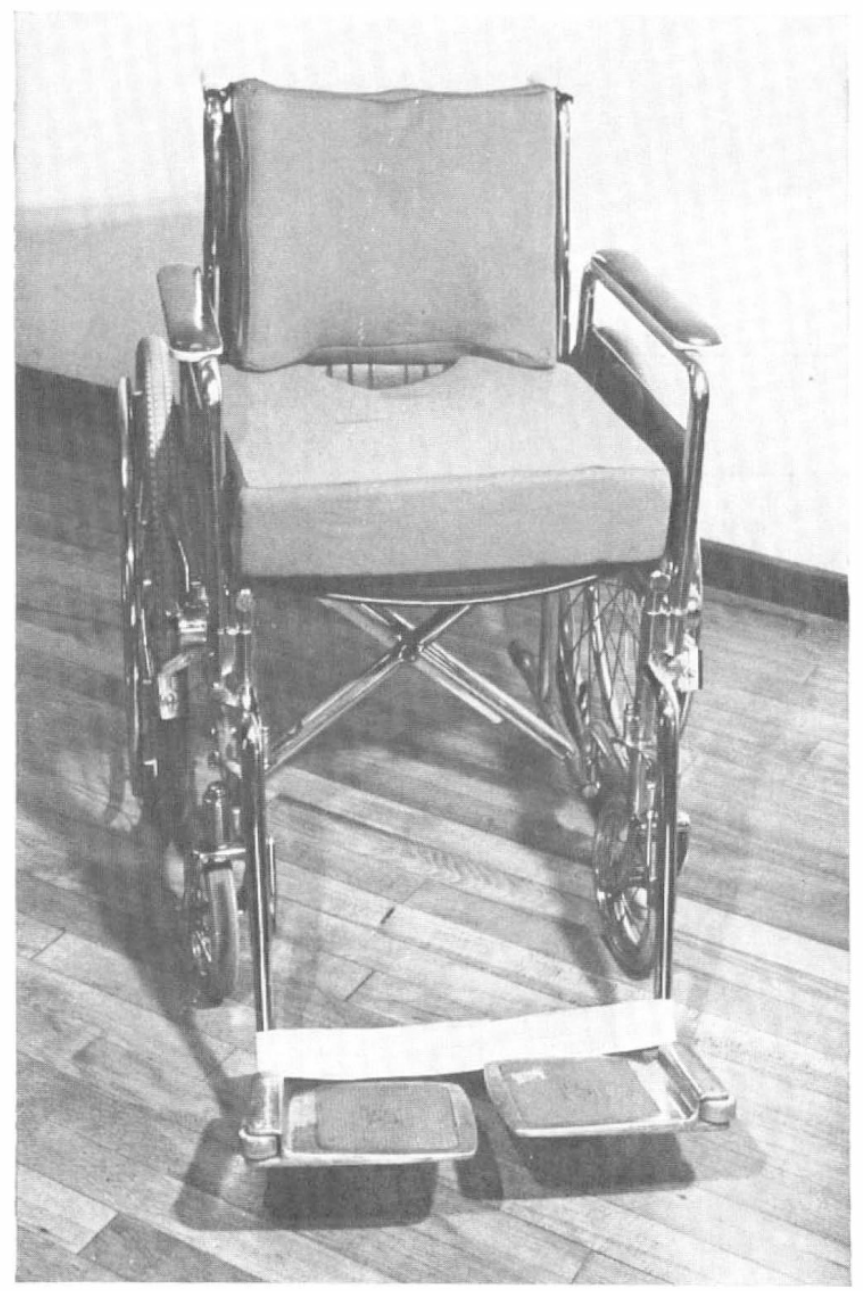

Fig. 4

Covered cushion and backrest in wheelchair. 


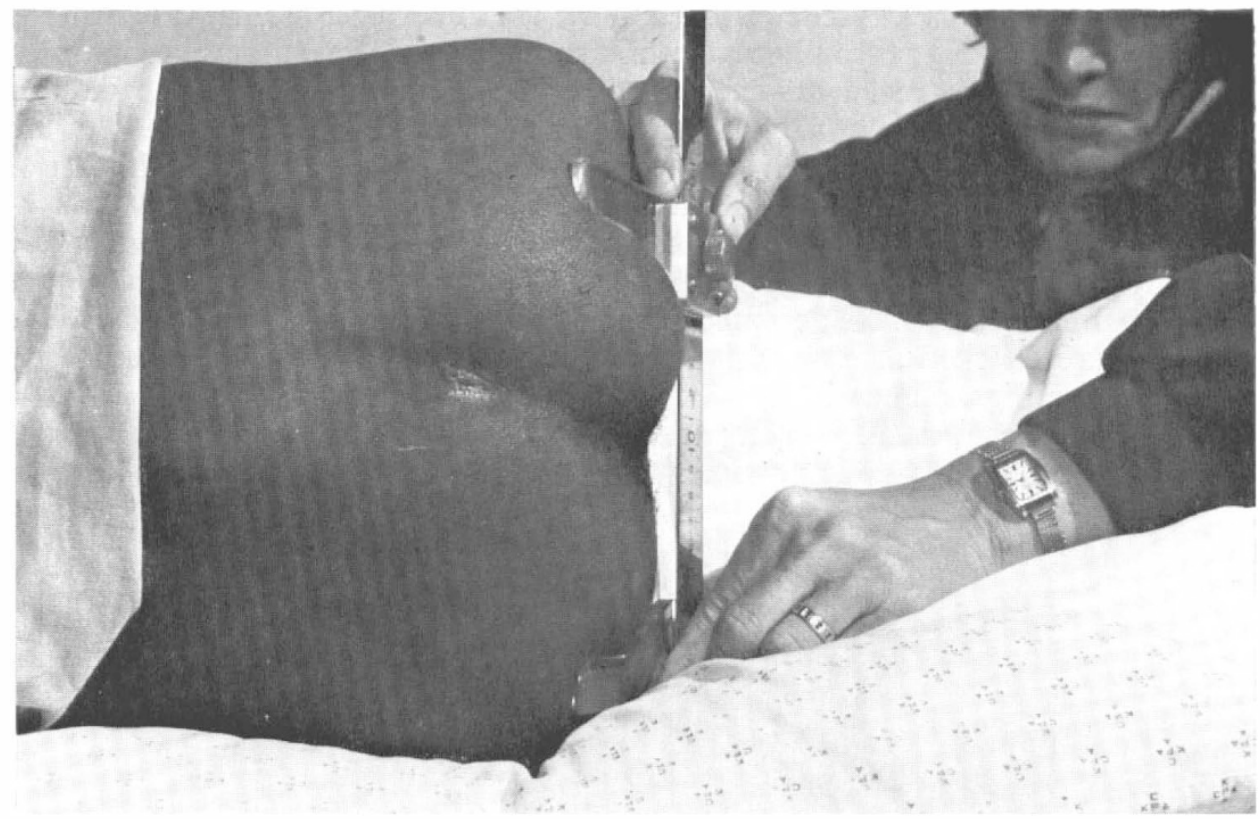

FIG. 5

Measurement between ischial tuberosities with patient lying in lateral position with hips and knees flexed to $90^{\circ}$.

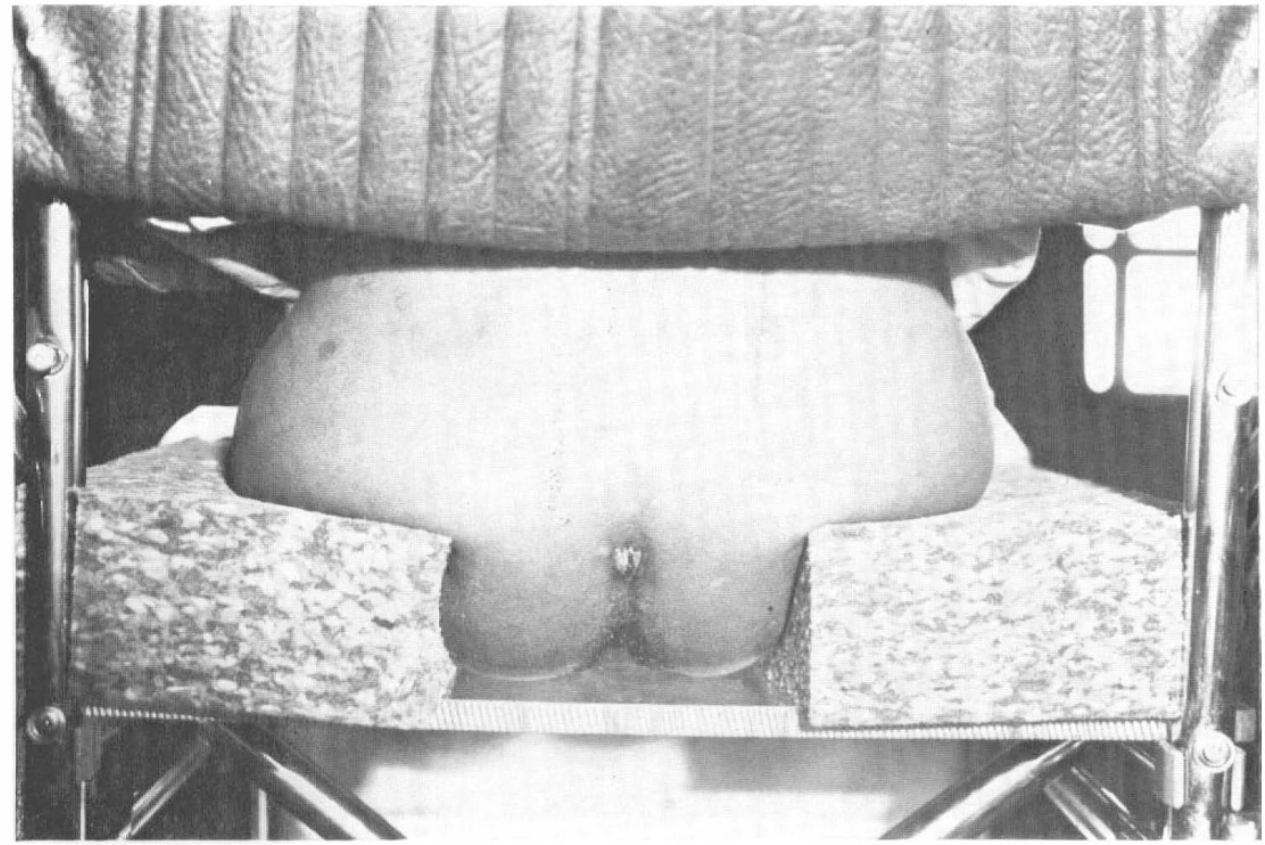

Fig. 6

Perspex seat wheelchair-trying for size of cushion cut-out. 


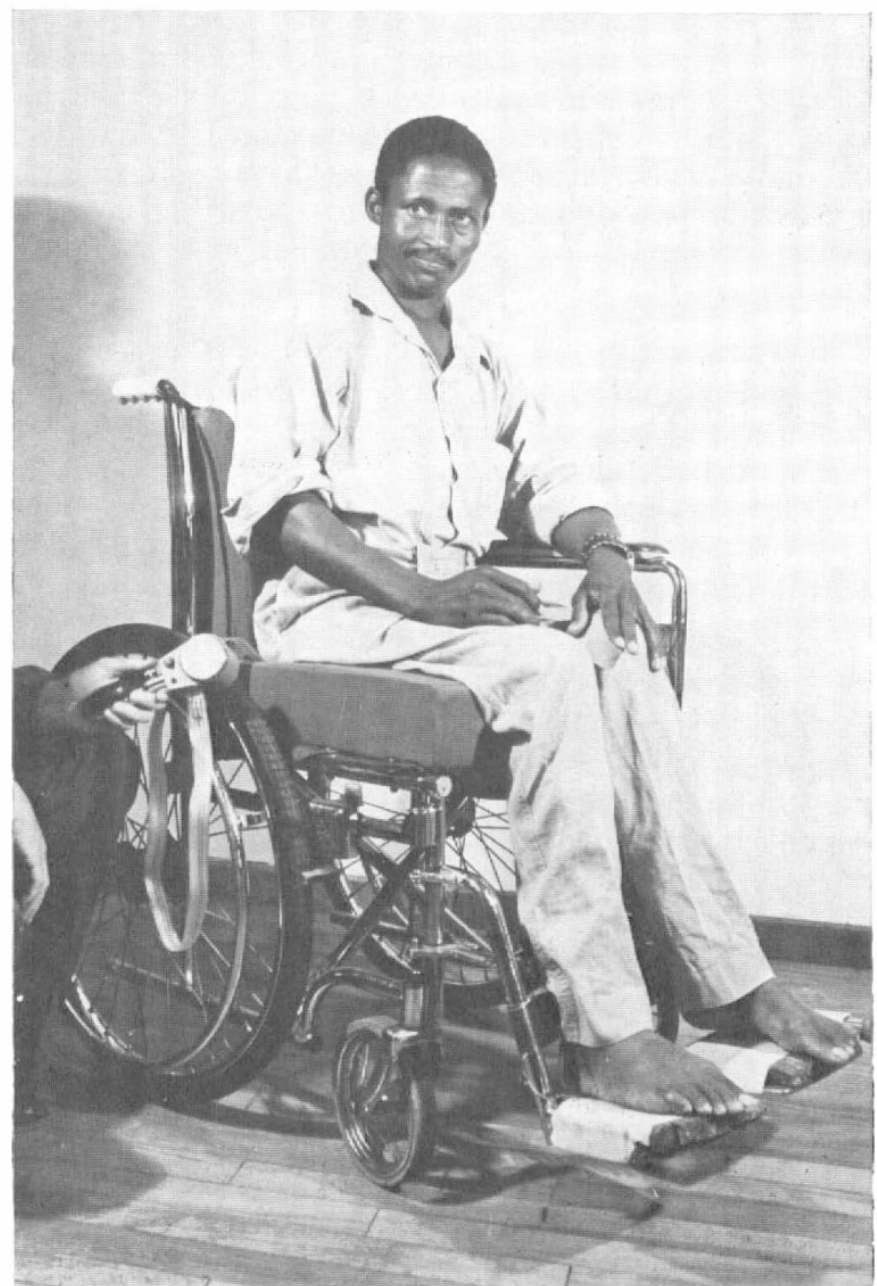

FIG. 7

Pressure measurements being taken.

\section{Evaluation of Results}

Over the initial I5-month period (October 1976 to September 1977) I9I patients attended the pressure clinic and were fitted with cushions. A survey was conducted in March 1978, the results of which are shown in Table I.

TABLE I

Patients

Number fitted October 1976 to December 1977

I9I

Untraceable at survey date

Not using their cushions Total in follow-up study 


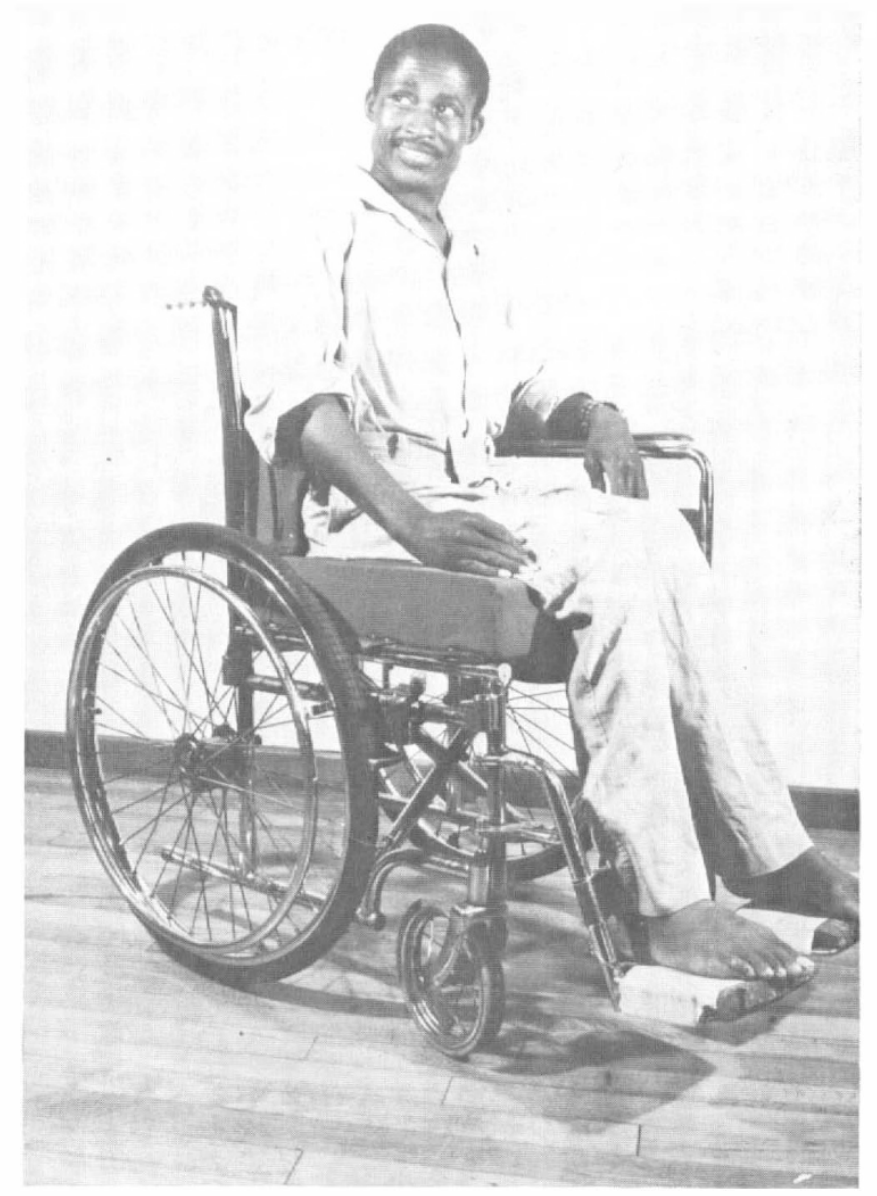

FIG. 8

Good posture.

\section{Sores which Healed}

The first patient to be fitted with a Paracare cushion was a young female laboratory assistant with a complete $\mathrm{T} 2$ neurological lesion of ro years duration who had a persistent ischial sore intermittently for just over I year and who was unable to remain at work for longer than a period of 3 weeks without a breakdown of tissue. She was fitted with her cushion when the sore was open and whilst receiving daily dressings and she remained at work sitting in her wheelchair. Three weeks later the sore was completely healed, it has not broken down since then, and she has not missed a day at work.

Subsequently I I similar cases with open ischial sores that were not treated surgically responded in a similar manner and have not broken down since.

A further 37 cases had either sacral split sores, undue ischial tissue marking or discoloration, or plastic surgery repair which was showing evidence of repeat 
early breakdown. All these have responded satisfactorily on the Paracare cushion and immobilisation in bed has been avoided.

Of the 56 cases who presented with sores of a varying severity in the sitting area when they were first measured and fitted with a cushion; 49 healed as stated above; of the remaining seven, two still had sores which were yet to heal at the time of the survey, but there was no deterioration despite remaining up in their wheelchairs and five were remitted for surgical treatment, prior to using their cushion.

\section{Patients who Developed Sores during the First Three Months on the Cushion}

Eleven patients developed small ischail sores during their first 3 months on the cushion. All of these were sitting on a cushion of the initial design which had a moulded curved hard base to accommodate the wheelchair seat sag. As a result of these sores materialising, the curved base was replaced by one of the same expanded polyurethane elastic foam as the cushion and no further similar problems have since arisen. All these sores healed when their cushions were modified.

\section{Patients Developing Sores after Discharge}

Seventeen patients developed sores after long term usage of the cushion. Of these seven presented with Trochanteric sores which were patently developed during bed rest. Four patients were of low intelligence and constantly misusing their cushions (e.g. one patient was observed sitting with the cut-out to the front of the chair and one was found to be keeping his cigarette box in the cut-out).

The remaining six patients exhibited sores on the trochanteric shelf, gluteal cleft and thighs and these must be classified as cushion sores. However two of these six patients had cut additional holes in the cushions to 'improve the design', one had broken down a thin area of scar tissue where he had previously had a caliper cuff-top pressure sore and subsequently a compound fracture of the femur through the original scar. The remaining three required cushion modifications.

\section{Conclusions}

The recent follow-up study of I66 Spinal patients fitted with special wheelchair support surfaces at the Conradie Hospital Pressure Clinic has shown that the methods employed have been successful in preventing and relieving pressure sores in 89 per cent of this patient population. Significantly, of the 56 patients presenting with open sores of varying severity or severe marking during cushion fitting 49 patients (85 per cent) healed their sore or lesion whilst sitting and have had no recurrence.

I Io cases received these cushions as a prophylactic measure: IOI remained sore free, three developed trochanteric sores in bed. Only four of the entire group of I9I found the cushion uncomfortable or not to their liking, the vast majority have been extremely satisfied and find that they are more stable in their wheelchairs and that their sitting posture is markedly improved, and that the dreaded fear of a sitting sore is virtually a thing of the past.

Acknowledgements. This work has been funded by grants from the Harry Crossley Foundation, Medical School, University of Cape Town and the Cape Cripple Association. We wish to express our gratitude to Dr D. Smith, the Medical Superintendent at Conradie Hospital for his active support of this work. In addition, we thank Mr D. Abrahams of the Bio-engineering Department, Conradie Hospital, for his help in establishing our system, and we also acknowledge the support and enthuiasm of all those members of 
the Department of Physiotherapy and Occupational Therapy at Conradie Hospital without whose help this project could never have been started.

\section{RÉSUMÉ}

La récente poursuite d'étude sur 166 patients, équipés de fauteuils roulants avec des surfaces spéciales de support, nous montre que les méthodes employées empêchent et soulagent avec $89 \%$ de succès les blessures de pression de ces malades.

A noter: des 56 patients qui avaient des blessures ouvertes de gravité divers ou des marques graves au moment de l'essayage des supports (coussins) 49 patients (soit $85 \%$ ) cicatrisèrent leurs blessures ou lésions tout en étant assis et n'eurent plus de renouvellement.

I Io patients reçurent ces coussins comme mesure prophylactique: IOI restèrent sans blessures, 3 contractèrent des blessures trochanterique au lit. Seulement 4 du groupe entier de I9I patients trouvèrent les coussins inconfortables. La grande majorité a été très satisfaite. Les patients trouvent qu'ils sont plus stables dans leurs fauteuils roulants et que la posture assise s'est améliorée. Aussi la crainte des blessures de pression de posture assise est devenue pratiquement quelque chose du passé.

\section{ZUSAMMENFASSUNG}

Es wurden I66 Querschnittsgelähmte Patienten in Conradie Hospital mit einem hesonderen Druckverteilungs Sitzkissen für den Rollstuhl versorgt.

Der Nachuntersuchungsbefund zeigte dass die angewandten Methoden in $89 \%$ dieser Patienten Dekubiti verhüten und heilen.

Bedeutungsvoll ist, dass während der Kissenversorgung von 56 Patienten mit Dekubiti von unterschiedlichen Grad oder übermässiger Andeutung der Druckstellen, 49 Patienten (85\%) ihre Dekubiti und Druckstellen auf diesem Spezialsitzkissen heilten.

I IO Fälle bekamen diese Kissen zur Vorbeugung von Dekubiti: Ior dieser Fälle blieben ohne Dekubiti und 3 entwikkelten trochanterische Dekubiti im Bett. Nur 4 aus dieser Gruppe von I9I Patienten empfanden das Kissen unbequem. Die Mehrheit ist sehr zufrieden, fühlt sich sicherer im Rollstuhl und hat eine bessere Haltung. Sie haben auch keine Befürchtungen mehr Dekubiti zu entwickeln.

\section{REFERENCES}

Burton, A. C. \& Yamada, S. (I95I). F. Appl. Physiology, 4, 329.

MANLEY, M. T., WAKEFIELD, E. \& KeY, A. G. (I977). The prevention and treatment of pressure sores in the sitting paraplegic. South Africa Medical fournal, 52, 771-774. 